\title{
Particulate Organic Carbon of Bottom Boundary and Submarine Cavern Waters of Tropical Coral Reefs*
}

\author{
Henry M. Reiswig \\ Redpath Museum, McGill University, 859 Sherbrooke Street West, Montreal, Quebec, H3A 2K6 Canada
}

\begin{abstract}
Particulate organic carbon was measured in water samples from the bottom boundary layer of open reefs, a submarine cavern, and intermediate depths over coral reefs in the tropical Pacific (Guam) and Atlantic (Barbados) Oceans. Differences in POC content between these geographically disjunct areas are insignificant and, when compared with previously published values, suggest that

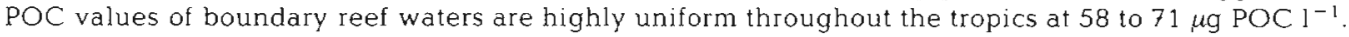
Vertical profiles of $\mathrm{POC}$ at outer deep reef stations are uniform and contrast with a previously published inshore profile. With relation to previous observations the profiles suggest that benthic communities may be important in structuring intermediate levels of the over-reef water column.
\end{abstract}

\section{INTRODUCTION}

Our limited knowlege of organic carbon in coral reef waters stems largely from analyses of water characteristics during transit across shallow reef-crests to back-reef or lagoon areas (Sargent and Austin, 1954; Odum and Odum, 1955; Johannes et al., 1972; Marshall et a1., 1975; Westrum and Meyers, 1978). These studies have focussed principally on surface or nearsurface waters $(0$ to $-1 \mathrm{~m})$, since the major goal of such studies has been the demonstration of changes in water characteristics resulting from dynamic processes taking place at or near the reef-crest. With the advent of readily available SCUBA capabilities in recent years, biological and geological reef research has been increasingly directed toward the deeper, fore-reef areas $(-10$ to $-60 \mathrm{~m})$, Ladd's 'mare incognitum', because of the greater complexity of community structure, higher faunal diversity, larger biomass density, and the controversial importance of depositional processes in vertical and horizontal extensions of reef structure in these areas (Smith and Harrison, 1977).

\footnotetext{
- This work was supported by a National Geographic Society Research and Exploration grant to W. D. Hartman and a National Research Council of Canada operating grant to the author
}

In spite of the relatively larger biomass of the deeper fore-reef faunas, the impact of these communities on general over-reef and bottom boundary water characteristics has not been directly assessed, due to variable circulation patterns, and inherent sampling problems. At the same time, information obtained in shallow reef-crest transit studies noted above is of questionable applicability to biologists and geologists concerned with exchanges taking place between the deeper benthos and the boundary layer. In order to extrapolate from the extensive physiological literature resulting from laboratory studies of coral reef organisms to the development of an appreciation of the dynamic processes taking place between the fore-reef communities and oceanic water impinging on the reef front, we require detailed vertical profiles of over-reef and offshore water characteristics, as well as considerably more information on the critical boundary water layer (Reiswig, 1972). Clearly, data on horizontal and vertical water movement and rates of mixing within and between layers are essential for such analyses. The data presented here on particulate organic carbon (POC) in bottom boundary water of open reefs, waters of a submarine cavern and vertical profiles of over-reef waters represent an initiation of investigation of forereef water characteristics, with the intent of unveiling evidence of the possible magnitude of dynamic exchanges occurring in this community. 


\section{MATERIALS AND METHODS}

Water samples were collected in the Pacific Ocean in August 1971 at Anae Island, Guam, Marianas Is. $\left(13.356^{\circ} \mathrm{N}, 144.535^{\circ} \mathrm{W}\right)$ and in the Atlantic Ocean in June through August 1976 off Holetown, Barbados $\left(13.170^{\circ} \mathrm{N}, 59.643^{\circ} \mathrm{W}\right)$. All samples were collected directly with the use of SCUBA in cleaned, stoppered ( $3 \mathrm{~cm}$ diam. plug), polyethylene bags by holding the unstoppered aperture forward at full arm extension while swimming transects at indicated depth (below) during daylight hours. At Guam, 6-l samples were taken (1) within the bottom boundary layer (within $1 \mathrm{~m}$ of the reef surface) on typical open, coral-dominated reefs within $100 \mathrm{~m}$ of the island at -9 to $-11 \mathrm{~m}$, and (2) in a dark submarine cavern located at the island shoreline at -5.5 to $-11 \mathrm{~m}$. Water conditions were consistently calm, with wave height less than $0.3 \mathrm{~m}$, gentle swells, and bottom horizontal currents less than $10 \mathrm{~cm} \mathrm{~s}^{-1}$. Within the cavern, swell-generated water oscillation was barely perceptible in main galleries, but exceeded $100 \mathrm{~cm} \mathrm{~s}^{-1}$ in peak translation in narrow channels. A through-flow current was not obvious. Samples within the cavern were taken in major galleries immediately upon entrance to prevent contamination by material dislodged from gallery walls and ceiling by exhaust bubbles. The Anae Island cavern consists of 3 interconnected galleries extending approximately $30 \mathrm{~m}$ into the island base with connections to open reef water through 3 narrow portals. It is typical of submarine caves and grottoes distributed throughout the tropics, with high light attenuation and a cryptic fauna dominated by sclerosponges, demosponges, brachiopods and foraminifera in its darker reaches (Jackson et al., 1971; Vasseur, 1974)

Immediately after collection, samples were chilled in ice water on board the diving vessel, returned to the University of Guam Marine Laboratory, there filtered gently $\left(0.7 \mathrm{~kg} \mathrm{~cm}^{-2}\right.$ absolute pressure $=1 / 3 \mathrm{~atm}$ 'suction') onto precombusted glass fiber filters (Reeve Angel $934 \mathrm{AH}-47 \mathrm{~mm}$, effective pore size 0.3 to $0.5 \mu \mathrm{m}$; Sheldon, 1972; Wetzel, 1972); finally the filters were rinsed with $4.5 \%$ sodium sulphate solution to remove the chloride. Zooplankton and large detrital particles (> $100 \mu \mathrm{m}$; here referred to as 'mesoparticulates') were counted with the aid of a dissecting microscope $(30 \times)$ and physically transferred to clean filters by forceps for separate analysis. Control filters were rinsed in sample filtrate and sodium sulphate solutions. The filter sets (controls, microparticulates $<100 \mu \mathrm{m}$ and mesoparticulates) were loosely wrapped in precombusted aluminum foil, stored under desiccant $\left(\mathrm{CaCl}_{2}\right)$, and transported in sealed containers to Yale University where organic carbon was measured by wet dichromate digestion (Strickland and Parsons, 1972).
Although this method has often been criticized (e.g. Wangersky, 1965) in regard to incomplete oxidation of refractory organics, high variability of filter blanks, non-discrete pore size of glass fiber filters, etc, it has distinct advantages over more recent methods for tropical studies. Tropical laboratories are plagued by problems of custom clearance of expensive equipment and chemicals, unavailability of specialized analyzers due to low equipment budgets, rapid equipment corrosion. lack of qualified service personnel and, more important, undependable refrigeration for storage and transport of frozen samples. These factors prevent or inhibit the use of modern analytic high temperature techniques. Direct comparison of wet digestion (persulfate) and high temperature analyses for total organic carbon (Sharp, 1973) indicate that for water samples from. above $-100 \mathrm{~m}$, the 'wet' method gave values of $85 \%$ of the latter, and such wet methods are considered acceptable, if not preferable, for shallow water work (Sharp, 1975). No direct comparison is available for dichromate vs high temperature analyses for POC, but the 0.85 value seems acceptable for present needs.

At Barbados, 4-1 water samples were collected as above from the bottom boundary water layer over open coral reefs 100 to $1,000 \mathrm{~m}$ offshore at -5.5 to $-15 \mathrm{~m}$ and from intermediate depths to provide vertical profiles over the deeper, offshore, bank-reef station (Macintyre, 1967). Samples were immediately returned to the Bellaires Research Institute where they were gently passed through a $100 \mu \mathrm{m}$ stainless steel sieve to remove mesoparticulates and gently filtered through precombusted glass fiber filters (Whatman $\mathrm{CF} / \mathrm{C}-47 \mathrm{~mm}$, effective pore size 0.5 to $0.7 \mu \mathrm{m}$; Quinn and Meyers, 1971; Sheldon, 1972) within 2 h of collection. Mesoparticulates were occasionally assessed in boundary waters and vertical profiles by difference in parallel analysis of total (unsieved) and sieved sample pairs. Organic carbon was measured at the Barbados laboratory by wet dichromate digestion within $8 \mathrm{~h}$ of sample collection.

\section{RESULTS}

As shown in Table 1, waters of the submarine cavern at Guam did not differ significantly (Wilcoxan two sample stat.) from the boundary waters of the surrounding reef in either micro- or total particulate organic carbon (POC). Meso-POC values suggest a slightly lower level of large particles in the cavern, although the difference is not significant. Numerical densities of both crustaceans and large detrital particles were slightly higher in reef samples (cavern/reef ratios: crustaceans $2.4 / 3.2 \mathrm{l}^{-1}$; detrital particles $0.9 / 1.2$ $1^{-1}$ ), but the overall numerical ratio for both particle 
Table 1. Particulate organic carbon (POC) of cavern and bottom boundary waters of coral reefs. Mean POC values are given in $\mu 9$ $1^{-1} \pm$ standard error, range and sample numbers in parentheses

\begin{tabular}{|c|c|c|c|c|}
\hline Location & $\begin{array}{l}\text { Depth } \\
(\mathrm{m})\end{array}$ & $\begin{array}{l}\text { Micro-POC } \\
1<100 \mid \mathrm{mm} j\end{array}$ & $\begin{array}{l}\text { Meso-POC } \\
(>100 \mu \mathrm{m})\end{array}$ & Total POC \\
\hline \multicolumn{5}{|l|}{ This study } \\
\hline Guam: Cavern & $5.5-11$ & $\begin{array}{c}57.0 \pm 4.0 \\
(40.6-81.5)(9)\end{array}$ & $\begin{array}{c}2.5 \pm 0.9 \\
(0.4-8.8)(9)\end{array}$ & $\begin{array}{c}59.5 \pm 4.2 \\
(42.1-82.4)(9)\end{array}$ \\
\hline Open reef & $9-11$ & $\begin{array}{c}53.7 \pm 2.7 \\
(42.8-69.4\}(13)\end{array}$ & $\begin{array}{c}4.6 \pm 1.3 \\
(0.7-15.7)(13)\end{array}$ & $\begin{array}{c}58.3 \pm 3.6 \\
(43.5-85.2)(13)\end{array}$ \\
\hline All samples & $5.5-11$ & $\begin{array}{c}55.1 \pm 2.3 \\
(40.6-81.5)(22)\end{array}$ & $\begin{array}{c}3.7 \pm 0.9 \\
(0.4-15.7)(22)\end{array}$ & $\begin{array}{c}58.8 \pm 27 \\
(42.1-85.2)(22)\end{array}$ \\
\hline Barbados: Reef & $5.5-15$ & $\begin{array}{c}55.2 \pm 2.9 \\
(30.1-87.4)(23)\end{array}$ & $\begin{array}{c}7.1 \pm 4.4^{\circ} \\
(-1.4-13.1)(3)\end{array}$ & $\begin{array}{c}71.1 \pm 9.2 \\
(53.7-82.6)\end{array}$ \\
\hline \multirow[t]{2}{*}{ Jamaica: Fore-reef (a) } & $\begin{array}{ll}15 & -52\end{array}$ & 63 & $<1$ (c) & $\begin{array}{c}63.9-3.3 \\
(53.3-70.8)(5)\end{array}$ \\
\hline & 5 & - & - & $70(d)(3)$ \\
\hline
\end{tabular}

types $(0.76)$ is not similar to the meso-POC ratio $(0.54)$ between the two habitats. Clearly the mesoparticles are simply larger on the open reef. The lack of significant differences between POC values of open reef and cavern waters suggests that nutrient availability is unlikely to be an important causal factor (or resultant of) the striking shift in faunal composition between these habitats.

Bottom boundary waters of open reefs in both Guam and Barbados were found to be strikingly similar in

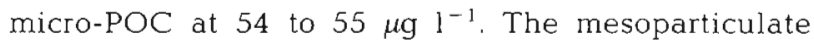
fraction of Pacific reef samples consisted largely of small, slow-moving copepods which were easily captured by the method of collection. Barbados boundary water samples were conspicuously devoid of zooplankton (day sampling precluded capture of nocturnal, resident demersal zooplankton), and the occasional large particles noted were detrital or algal (Trichodesmium thiebautii) in nature. The differences between Barbados and Guam POC fractions and total POC are not statistically significant. Moreover, these values agree fairly closely with those of previous reports of Jamaican reef boundary waters, both over offshore, deep fore-reefs (Reiswig, 1972), where zooplankton were also noted to be absent or non-capturable, and the shallow, upper-terrace reef (Westrum and Meyers, 1978) (Table 1).

Three vertical profiles of POC were obtained within a 9-d interval at closely-placed stations over the Barbados outer bank reef at -12 to $-15 \mathrm{~m}$ (Fig. 1). The micro-POC (sieved) profiles are rather uniform within sample sets, indicating little or no water stratification over these deep stations. Large changes in micro-POC were obtained, however, throughout the water column over an interval of $2 \mathrm{~d}$, indicating horizontal translocation of the entire water column. Unfortunately data on thermal, salinity and density structure are not available for these samples. Mesoparticulate concentrations, as expected, show somewhat higher variability within single profiles, with larger planktonic organisms and detrital masses being irregularly captured in the bag samples.

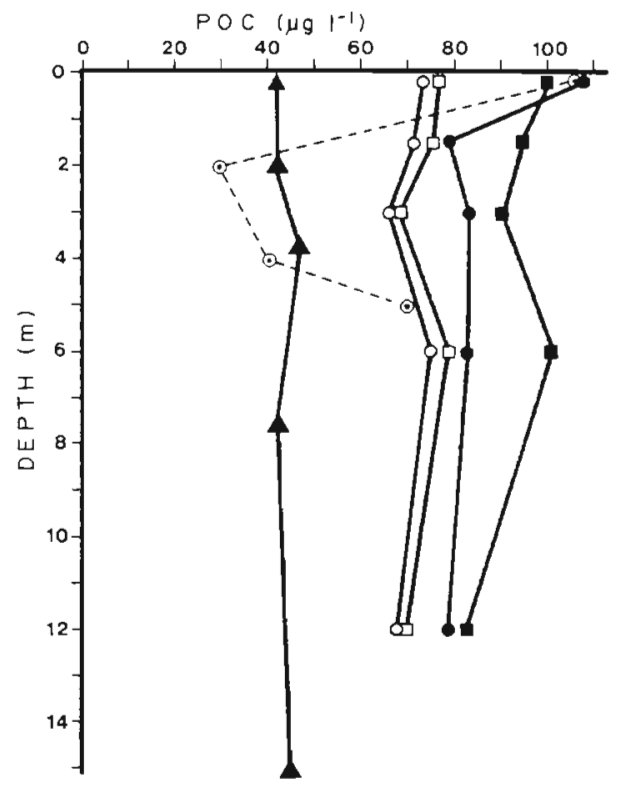

Fig. 1 Vertical profiles of particulate organic carbon (POC) in bank reef waters off Barbados. $\triangle 0900 \mathrm{~h}, 1$ Aug. 1976; 0 0800 h, 4 Aug. 1976; $\square 1300$ h 10 Aug. 1976. Open symbols: micro-POC $(>100 \mu \mathrm{m})$; solid symbols: total POC. Broken line: data from Jamaica (Westrum and Meyers, 1978) 


\section{DISCUSSION}

The importance of POC as a nutrient resource for major elements of coral reef benthos, sponges (Reiswig, 1971) and corals (Lewis and Price, 1976; Lewis, 1977 b), underscores the need for accuracy in measurement of POC values and the ability to detect slight changes in concentration as a result of utilization at the bottom boundary layer. Data presented here, and summarized for previous studies, indicate that POC of bottom boundary waters are surprisingly uniform over a variety of geographically separate coral reefs: 58 to $71 \mu \mathrm{g} \mathrm{POC} ~^{-1}$ (with Sharp correction: 68 to $84 \mu \mathrm{g}$ POC $\left.\mathrm{I}^{-1}\right)$. As a potential source for heterotrophic requirements of scleractinian corals the total POC measured here would amount to 40 to $49 \%$ (with Sharp correction 47 to $58 \%$ ) of the daily maintenance needs calculated by Lewis (1977 a) of $0.29 \mathrm{mg}$ dry organic matter (equivalent to approximately $145 \mu \mathrm{g}$ POC $\mathrm{l}^{-1}$ ). Simmons' (1979) estimate of available POC at Tague Bay reef, St. Croix, is based upon measurement of dry particulate matter only, with use of a general conversion value of $30 \%$ to estimate equivalent particulate organic matter. Not only is the accepted conversion factor (derived from oceanic Atlantic samples) unlikely to be appropriate for tropical near-shore waters with high calcareous content, but his estimate is given incorrectly as 'POC' rather than 'POM'. The equivalent value should be approximately $90 \mu \mathrm{g}$ POC $1^{-1}$ for his smallest size fraction, but this must be regarded as a high value until reasonable corrections for carbonate are applied.

The vertical profiles of POC at Barbados contrast strikingly with that given by Westrum and Meyers (1978) from the shallow terrace of Discovery Bay, Jamaica (Fig. 1), the only profile of POC in coral reef waters published to date. The profiles from the two different areas are not directly comparable in view of the Barbados stations being located at the offshore reef edge with no significant 'upstream' benthic community and the Jamaican station being located far inshore of an extensive upstream benthic community of high biomass density. The differences, when related to other circumstantial evidence, may reflect the activities of the upstream community. The water turnover rates of the fore-reef communities in Jamaica have been estimated to approximate the entire overlying water column over a 24 -h period (Reiswig, 1974). It has been shown that major elements of the boundary community remove POC at high efficiency - either in situ: $35.2 \%$ by sponges in single transit (Reiswig, 1971); or in turbulent mixed conditions in the laboratory: corals (Lewis, 1977 a). Large specimens of Porifera of the fore-reef are known to throw gametes several meters above the boundary layer, providing evi- dence that they may be significant in generating vertical mixing throughout a considerable water column depth. Finally, the profile of Westrum and Meyers shows obvious depletion of POC (and DOC - see their figures) in the intermediate layers. These items, when taken together and when compared to the situation in Barbados, suggest to me that the benthic community may extract large quantities of POC from a significant proportion of the overlying water column, and that deletion is seen in the inshore profile at Jamaica. Deletion is not present in the offshore profiles of Barbados, but it is expected to occur at stations inshore of the bank reef there. Westrum and Meyers' profile further suggests that POC depletion is intensified in intermediate layers going from offshore to inshore; entrainment of the entire water column across the inshore reef-crest by onshore wind stress, should result in condensation of POC stratification just seaward of the crest. Unless physical mixing is extreme at this point, the waters flowing over the crest may be highly structured vertically in terms of POC concentrations, and great care should be taken to sample the shallow (ca $0.5 \mathrm{~m}$ ) but complex water layer in transect studies of water flow across reef crests. Some of the differences previously noted between seaward and back-reef water samples may indeed be reflections of dynamic exchanges which had taken place far upstream in forereef boundary communities, rather than at the reef crest itself.

\section{LITERATURE CITED}

Jackson, J. B. C., Goreau, T. F., Hartman, W. D. (1971). Recent brachiopod-coralline sponge communities and their paleoecological significance. Science, N.Y 173: 623-625

Johannes, R. E., Alberts, J., D'Elia, C., Kinzie, R. A., Pomeroy, L. R., Sottile, W., Wiebe, W., Marsh, J. A. Jr, Helfrich, P., Maragos, J., Meyer, J., Smith, S., Crabtree, D., Roth, A., McCloskey, L. R, Betzer, S., Marshall, N., Pilson, M. E. Q., Telek, G., Clutters, R. I., DuPaul, W. D., Webb, K. L., Wells, J. M. Jr. (1972). The metabolism of some coral reef communities: a team study of nutrient and energy flux at Eniwetok. BioScience 22: 541-543

Ladd, H. S. (1961). Reef building. Science, N.Y 134: 703-715

Lang, J. C. (1974). Biological zonation at the base of a reef. A.m. Sci. 62: 272-281

Lewis, J. B., Price, W S. (1975). Feeding mechanisms and feeding strategies of Atlantic reef corals. J Zool, Lond. 176: $527-544$

Lewis, J. B. $(1977$ a). Suspension feeding in Atlantic reef corals and the importance of suspended partıculate matter as a food source. Proc. 3rd Int Coral Reef Symp. 1 $405-408$

Lewis, J. B. (1977 b). Processes of organic production on coral reefs. Biol. Rev. 52: 305-347

Macintyre, I. G. (1967). Submerged coral reefs, west coast of Barbados, West Indies. Canad. J. Earth Sc1. 4:461-474

Marshall, N., Durbin, A. G., Gerber, R., Telek, G. (1975). Observations on particulate and dissolved organic matter in coral reef areas. Int. Revue ges. Hydrobiol. 60: 335-345 
Odum, H. T. Odum, E. P. (1955). Trophic structure and productivity of a windward coral reef community. Ecol Monogr. 25: 291-320

Quinn, J. G., Meyers, P. A. (1971). Retention of dissolved organic acids in seawater by various filters. Limnol Oceanogr. 16: 129-131

Reiswig, H. M. (1971). Particle feeding in natural populations of three marine demosponges. Biol. Bull. mar. biol. Lab. Woods Hole 141: 568-591

Reiswig, H. M. (1972). The spectrum of particulate organic matter of shallow-bottom boundary waters of Jamaica Limnol. Oceanogr $17 \cdot 341-348$

Reiswig, H. M. (1974). Water transport, respiration and energetics of three tropical marine sponges. J. exp. mar Biol. Ecol. 14: 231-249

Sergent, M. C., Austin, T. S. (1954). Biologic economy of coral reefs. U.S. Geol. Surv. Prof. Pap. 260-E: 293-300

Sharp, J. H. (1973). Total organic carbon in seawater - comparison of measurements using persulfate oxidation and high temperature combustion. Mar. Chem. 1:211-229

Sharp, J. H. (1975). Gross analyses of organic matter in seawater: why, how, and from where. In: Church, T. M. (ed.) Marine chemistry in the coastal environment. Am. Chem.
Soc. Spec. Ser No. 18, pp. 682-696

Sheldon, R. W. (1972). Size separation of marine seston by membrane and glass-fiber filters. Limnol. Oceanogr 17 : $494-498$

Simmons, G. M. Jr. (1979). Abundance and size distribution of particulate matter fractions near a Caribbean bank barrier reef. Mar Ecol. Prog. Ser 1:7-11

Smith, S. V., Harrison, J. T (1977). Calcium carbonate production of the mare incognitum, the upper windward reef slope, at Enewetak Atoll. Science, N.Y 197: 556-559

Strickland, J. D. H., Parsons, T. R. (1972). A practical handbook of seawater analysis. Bull. Fish. Res. Bd Can. 167: $1-310$

Vasseur, P. (1974). The overhangs, tunnels and reef galleries of Tulear (Madagascar) and their sessile invertebrate communities. Proc. 2nd Int. Coral Reef Symp. 2: 143-159

Westrum, B. L., Meyers, P. A. (1978). Organic carbon content of seawater from over the Caribbean reefs. Bull. mar. Sci. 28: $153-158$

Wetzel, R. G., Rich, P. H., Miller, M. C., Allen, H. L. (1972). Metabolism of dissolved and particulate detrital carbon in a temperate hard-water lake. Mem. Ist. Ital. Idrobiol. 29 (Suppl.): 185-243

This paper was presented by Dr D. Kühlmann; it was accepted for printing on February 10, 1981 